\title{
The Insight Study of Consumer Life-styles and Purchasing Behaviors in Songkla Province, Thailand
}

\author{
Wassana Suwanvijit (Corresponding author) \\ Faculty of Economics and Business Administration, Thaksin University \\ 140 Karnchanavanich Road, Muang, Songkla, 90000, Thailand \\ E-mail: swassana@gmail.com \\ Sompong Promsa-ad \\ Faculty of Economics and Business Administration, Thaksin University \\ 140 Karnchanavanich Road, Muang, Songkla, 90000, Thailand \\ E-mail: promsa_ad@yahoo.com
}

The research is sponsored by Faculty of Economics and Business Administration, Thaksin University

\begin{abstract}
Purposes of the insight study of consumer life-styles and purchasing behaviors in Songkla province, Thailand" were: 1) to understand consumer life-styles and purchasing behaviors; 2) to determine the factors affecting consumer life-styles and purchasing behaviors; and 3) to examine consumer attitudes among traditional and modern trade channels. The data were collected through self-administered questionnaires among a sample of 300 consumers in Songkla province. Descriptive and inferential statistics, composed of frequency, percentage, $t$-test, and multiple regression, were used in the data analysis. The results indicated that consumer life-styles oriented in outgoing, dependent in decision making, economically conscious, necessity and convenience concern. The purchasing behaviors were focus on product variety, facility \& service, outlet location, pricing, product quality, refreshment of product and product modernity. At a 0.05 statistically significant level, demographic and socio-economic characteristics affecting consumer life-styles and purchasing behaviors. There were discernable consumers' attitudinal differences between traditional and modern trade channels.
\end{abstract}

Keywords: Consumer, Traditional trade, Modern trade, Life-style, Behavior, Purchasing

\section{Introduction}

Consumer life-styles and purchasing behaviors have been always a great interest to marketers. The knowledge of consumer behavior helps the marketer to understand how consumers think, feel and select from alternatives like products, brands and the like and how the consumers are influenced by their environment, the reference groups, family, and salespersons and so on. Life-styles are not held to the same degree by everyone. The identification of life-styles could have important implications for marketing strategy decisions. Another important characteristic of life-styles is that they are derived from and personalized through social and cultural learning and identify consumer demographics (i.e. age, occupation), as the personal factors influencing consumers' behavior. Thus, a scrutiny of the relationship between consumer demographics and life styles is likely to provide marketing managers with valuable insights for market segmentation, value creation, product positioning/re-positioning, and promotional decisions (Manrai 1996; Kahle, 1999, 2003). Life-style segmentation is based on the idea that the more you know and understand about consumers, the more effectively you can communicate and market to them. The underlying assumption here is that consumers express their personalities through their behaviors. People with different personalities exhibit different behaviors or similar behaviors for different reasons (Morgan, 1993). Life-style retailing can be described as the policy of tailoring a retail offer, or a portfolio of retail offers, closely to the life styles of specific market segments (Blackwell and Talarzyk, 1983). For instance, Wal-Mart tailors its merchandising offerings to the specific needs of diverse cultural groups with distinct life-style-orientations (i.e. African American, Hispanic American, and White American). There are numerous examples of life-style retailing, e.g. Next, the Gap, Laura Ashley, Denim, No Fear, Quicksilver, and Benetton (Helman and De 
Chernatony, 1999). Each of these embodies a distinct set of life-style values, which appeal to a particular consumer segment. A further development in retailing has been the adoption of own-brand strategies, and thus a number of retail offers in the marketplace can be viewed as life-style retail brands (Helman and De Chernatony, 1999). Life-style marketing and merchandising have increasingly come to dominate how retailers approach apparel, and this has powerfully impacted how denim is offered to different target markets with different life-style orientations (Duff, 2001). For example Sears, one of the best known retailers, after much segmentation researchers in the USA tried to undertake focused life-style analysis for certain product categories in the 2000s. Sears updates its operations; changes implemented aim to streamline and redefine its company image (USA Today, 2001). Understanding consumer life-styles and value orientations in any areas can be very useful in profiling an individual consumer and/or targeting consumer groups for marketing planning purposes. Past consumer behavior and psychology literature has identified different types of consumer life-style groups. Each group has its own unique demographic, socio-economic, and behavioral characteristics. As such, consumer life-styles as correlation of purchase are being utilized by such target markets as quality seekers, novelty/fashion seekers, comparison shoppers, information seekers, and brand loyal and habitual consumers (Schuster and Dufek, 2004). Kanhasiri (2005) used Kortler's model of buyer behavior to show the factors affecting the consumer's decision on buying shoes of students in Ho Chi Minh City, Vietnam. Andersone and Gaile-Sarkane (2008) analyzed the theoretical aspects of consumer behavior and factors that influences them to understand the particularities of different factors and their role in consumer behavior.

Songkla is a hub of commercial and investment province in Southern Thailand. The map of Songkla can be seen in Figure 1. It also a well known destination for tourists from neighboring countries likes Malaysia and Singapore. With high potential economic growth and purchasing power comparable with Bangkok, Songkhla attracts various retailers both giant domestic and international players. As a result, there are many kinds of retail business in Songkla including traditional trade (provision shop, local supermarket and mini-mart) and modern trade (hypermarket, supermarket, convenience store, etc.). There is a strong competition among these retail businesses and modern trade tend to do better as it can catch more customers regarding that it is a new entrants to the market. The situation requires traditional trade to change the way to do business to survive in such environments. One local wholesaler has launched its mini-mart franchise in order to accelerate its stock burn rate, but the success of the program is in doubt. Thus, a study of consumer life-styles and purchasing behavior can help companies to gain a better understanding and planning on doing business in Songkla in order to gain a critical strategic advantage.

The specific objective of this exploratory research study were: 1) to understand consumer life-styles and purchasing behaviors; 2) to determine the factors affecting consumer life-styles and purchasing behaviors; and 3) to examine consumer attitudes among traditional and modern trade channels.

\section{Methodology}

The data for this study were collected through self-administered questionnaires. The data were collected through a purposive and quota sampling method among a sample of 300 consumers at Songkla province. Before the survey, a pre-test of the questionnaire was undertaken with a small group of respondents in both localities, and the results were satisfactory. Interviews were conducted by marketing research students under the supervision of our researchers.

To understand consumer life-styles and purchasing behaviors, descriptive statistics, composed of frequency, and percentage were used in the analysis.

To determine the factors affecting consumer life-styles and purchasing behaviors, simple regression and multiple regressions were used in the analysis.

To examine consumer attitudes among traditional and modern trade channels, descriptive statistics and inferential statistics composed of mean and t-tests were performed on respondents' reactions.

SPSS Version 15.0 (SPSS Inc., 2006) was used for data management and analyzing the data.

\section{Findings and discussion}

Table 1 shows demographic and socio-economic characteristics of the survey respondents.

The research findings were as follow:

\subsection{Consumer life-styles and purchasing behaviors were as follow:}

3.1.1 Shopping frequency: Most of consumers go shopping 3 times a month or more than.

3.1.2 Shopping time: Consumers like shopping at the time between $5.00-7.00 \mathrm{pm}$ or the time after worked (or studied).

3.1.3 How to go shopping: Consumers frequently go shopping by motorcycle or car, and going with their friend than going alone.

3.1.4 Favorite channel: Provision shop, convenience store and fresh market are popular channels than others. 
3.1.5 Favorite goods: Consumers often purchase food $\&$ drink goods and necessary goods including bakery \& bread.

3.1.6 Decision making: More than $80 \%$ of consumers prefer to have purchasing decision and choosing outlet for shopping by themselves.

3.1.7 Spending rate (per time): Average spending rate was approx. 550 baht per time. Consumers prefer paying cash than using credit card. However, some consumers also have member card of some modern trade, such as 7-eleven, Tesco Lotus, etc.

3.1.8 Reasons in choosing outlet: Most consumers preferred the outlets which have more product variety, have good location, and have reasonable retail price.

3.1.9 Reasons in choosing goods: The main factors that consumers interesting in goods or brand choosing were retail price and refreshing of goods. They also considered about products quality and tried to find the modern products.

3.1.10 Service expect: They also concern about new product introduction service, car park, and after sales service.

3.1.11 Promotion expects: They suggested that consumer promotion is one of the factors affected sales. The best promotion in consumer's eye was a sale or special price promotion. However, some consumers like to have free premium such as glass, raw cotton shopping bag, etc.

The findings lead to distinct consumer life-styles and purchasing behaviors as shown in Figure 3. These findings can help retail companies in Songkla to understanding consumers and know how to design the suitable strategy plan.

3.2 By using Enter method in regression analysis at a 0.05 statistically significant level, the factors affecting consumer life-styles and purchasing behaviors were as follow:

3.2.1 The factor affecting spending per time was consumer income. This factor can explain the changing in consumer spending per time at $14.7 \%$

3.2.2 The factors affecting shopping time, composed of gender, income and status. Nevertheless, these factors can explain the changing in shopping time only at $5.8 \%$

3.2.3 The factors affecting service expect, composed of consumer hobby and family size. Although, these factors can explain the changing in service expect of consumer only at $3.4 \%$

3.2.4 The factor affecting favorite goods was consumer income. But even so, this factor can explain the changing in favorite goods only at $2.8 \%$

3.2.5 The factors affecting the shopping frequency, compose of consumer income and domicile. However, these factors can explain the changing in shopping frequency only at $2.3 \%$

3.2.6 The factor affecting the reasons in choosing goods (or brand) was family size. But, this factor can explain the changing in reasons in choosing goods or brand only at $0.4 \%$

3.2.7 Demographic and socio-economic factors did not influence on how to go shopping, favorite channel, purchasing decision making, reasons in choosing outlet and sales promotion expect.

3.3 There were discernable consumers' attitudinal differences between traditional and modern trade channels at a 0.05 statistically significant level in the statements of location, atmosphere, sales service, price, distribution, publicity, promotion, product quality, modernity of product, open-close time, product variety and integrated service as shown in Table 2. Consumers in Songkla have good attitude in every statements of modern trade outlet, however, the average attitude in traditional trade was fair. These differences may be used to establish a basis for the creation of different marketing plans, strategies, and programs. In particular, different promotional and target marketing approaches may be used in reaching different pockets of consumers.

From the findings, there is a room for improvement and a position for those traditional trades as customers favored channel are provision shop, convenience store and fresh market and preferred payment is in cash. It implies that most customers prefer to buy from the shop close to their homes or communities in traditional way. Traditional trade can employ this strength and add more what consumers looking for such as new product introduction service or after sale service to compete more effectively.

\section{Recommendation for future research}

Consumer life-style analysis provides a greater understanding of consumers' buying and consumption behaviors. That is, who buys what products? One can influence their purchasing and consumption differences by appealing to their life-style orientations, wants, and needs. For instance, consumers who are primarily motivated by achievement look for products and services that demonstrate success to their peers. It becomes very important for traditional trade to understand what modern trade consumers' needs are and deliver not only appropriate products and services, but appropriate and suitable benefits for the life-styles of both traditional and modern trade consumers. Companies in both trades can apply the results to understand their uniquely dynamic and ever changing consumers better. By looking at the 
survey data, one can make informed decisions on which outlets standardized marketing strategies should be used and in which outlets localized types of marketing strategies should be used by companies. Also, companies planning on doing business in Songkla province, Thailand can gain a better understanding and a critical strategic advantage by using the survey findings that explain the underlying dimensions and characteristics of Songkla consumers. For policy makers, who concern about fair competition and the survival of local player, can use the information from the findings to set up appropriate policy and the way to foster those local trade in a sustainable manner rather than rely only on law enforcement.

A study of consumers may produce different life-style profiles than the ones presented here due to this study only examined consumer life-styles and purchasing behaviors within the framework of product group (form). Additional studies may look at consumer life-styles by use of product brands and even product options.

\section{References}

Andersone, Ieva., Gaile-Sarkane, Elina. (2008). Influence of factors on consumer behavior. Proceeding of the $5^{\text {th }}$ International Scientific Conference Business and Management' 2008, May 16-17, Vilnius, Lithuania.

Blackwell, R.D., \& Talarzyk, W. (1983). Life-style retailing: competitive strategies for the 1980s. Journal of Retailing, Winter, 59(4), 7-27.

Duff, M. (2001). Denim category evolves under life-style influence. Design Retailing Today, 40 (8), 6-25.

Fraj, E., Martinez, E. (2006). Environmental values and lifestyles as determining factors of ecological consumer behavior: an empirical analysis. Journal of Consumer Marketing, 23(3), 44-133.

Harcar, Talha. (2008). Life-style orientation of rural US and Canadian consumers. Asia Pacific Journal of Marketing and Logistics, 20(4), 433-454.

Hawkins, D., Best, R.J., \& Kenneth, C.A. (1998). Consumer Behavior Building Marketing Strategy, Irwin/McGraw-Hill.

Helman D., \& De Chernatony, L. (1999). Exploring the development of life-style retail brands. The Service Industries Journal, 19(2), 49-68.

Kanhasiri, Chitpan. (2005). Factors affecting the consumer's decision on buying shoes: A case study of students in Ho Chi Minh City, Vietnam. The University of the Thai Chamber of Commerce.

Map of Southern Thailand. [Online] Available: http://www.thaihotelplan.com/south/images/Southern_Thailand_Map.png (Jan 12, 2009)

Orsay K. (2005). Exploring buyer life-style dimensions and ethnocentrism among Canadian consumers: an empirical study. The Business Review, Cambridge, 4(1), 17-210.

Peter, J.P., \& Donnelly, J.H. (2004). Marketing Management: Knowledge and Skills. McGraw Hill/Irwin, NY, 28-37.

Peter, J.P., \& Olson, J. (2005). Consumer Behavior and Marketing Strategy. McGraw Hill/Irwin, New York, NY.

Pirjo, H., \& Ottar, O.S. (2004). Preference-based segmentation: a study of meal preferences among norwegian teenagers. Journal of Consumer Behaviour, 3(3), 51-235.

Sears updates its operations; changes aim to streamline, redefine retailer's image. (2001). USA Today, Arlington, 29 October, B04.

Solomon, M.R., Zaichkowsky, J., \& Polegato, R. (1999). Consumer Behavior: Buying, Having, and Being. Prentice-Hall Canada Inc., Scarborough, Ontario, 187.

Spielvogel, C. (1989). Global consumer segmentation crosses national lines. Financier, pp. 37-40.

SPSS Version 15.0. (2006). SPSS Inc. [Online] Available: http://spss.com (Oct 21, 2008).

Wagner, A.K., \& Wedel, M. (1995). Life-style segmentation with tailored interviewing. Journal of Marketing Research, August, 32, 17-308.

Wansink, B. (2000). New techniques to generate key marketing insights. Marketing Research, 12(2), 28-36. 
Table 1. Demographic and socio-economic characteristics of sample.

\begin{tabular}{|c|c|c|}
\hline Detail & Frequency & Total Percent \\
\hline \multicolumn{3}{|l|}{ Gender } \\
\hline Male & 135 & 45.0 \\
\hline Female & 165 & 55.0 \\
\hline Total & 300 & 100.0 \\
\hline \multicolumn{3}{|l|}{ Age category } \\
\hline$<18$ & 67 & 22.3 \\
\hline $18-23$ & 88 & 29.4 \\
\hline $24-30$ & 79 & 26.3 \\
\hline $31-40$ & 42 & 14.0 \\
\hline$>41$ & 24 & 8.0 \\
\hline Total & 300 & 100.0 \\
\hline \multicolumn{3}{|l|}{ Education } \\
\hline Less than bachelor & 105 & 35.0 \\
\hline Bachelor & 172 & 57.3 \\
\hline \multirow[t]{2}{*}{ More than bachelor } & & 76.7 \\
\hline & 23 & \\
\hline Total & 300 & 100.0 \\
\hline \multicolumn{3}{|l|}{ Occupation } \\
\hline Government official & 91 & 30.3 \\
\hline Company employee & 81 & 27.0 \\
\hline Business owner & 48 & 16.0 \\
\hline Student \& unemployment & 80 & 26.7 \\
\hline Total & 300 & 100.0 \\
\hline \multicolumn{3}{|l|}{ Incomes } \\
\hline \multirow[t]{2}{*}{$<8,000$ baht } & 87 & \\
\hline & & 29.0 \\
\hline $8,001-15,000$ baht & 161 & 53.7 \\
\hline$>15,001$ baht & 52 & 17.3 \\
\hline Total & 300 & 100.0 \\
\hline \multicolumn{3}{|l|}{ Status } \\
\hline Single & 199 & 66.3 \\
\hline Married & 96 & 32.0 \\
\hline Divorced & 5 & 1.7 \\
\hline Total & 300 & 100.0 \\
\hline \multicolumn{3}{|l|}{ Religion } \\
\hline Buddhism & 198 & 66.0 \\
\hline Islam & 102 & 34.0 \\
\hline Others & 3 & 1.0 \\
\hline Total & 300 & 100.0 \\
\hline \multicolumn{3}{|l|}{ Family size } \\
\hline 1 person & 22 & 7.3 \\
\hline 2 persons & 43 & 14.3 \\
\hline 3-4 persons & 200 & 66.7 \\
\hline$>4$ persons & 35 & 11.7 \\
\hline Total & 300 & 100.0 \\
\hline
\end{tabular}


Table 2. Factors affecting consumer life-styles and purchasing behaviors

\begin{tabular}{|c|c|c|c|c|c|c|c|c|c|c|}
\hline Factors & $\begin{array}{c}\mathrm{Ag} \\
\mathrm{e}\end{array}$ & $\begin{array}{l}\text { Gend } \\
\text { er }\end{array}$ & $\begin{array}{l}\text { Educati } \\
\text { on }\end{array}$ & Status & $\begin{array}{c}\text { Religio } \\
\mathrm{n}\end{array}$ & $\begin{array}{c}\text { Occupatio } \\
n\end{array}$ & $\begin{array}{l}\text { Inco } \\
\text { me }\end{array}$ & $\begin{array}{l}\text { Famil } \\
\text { y size }\end{array}$ & $\begin{array}{c}\text { Hobb } \\
\text { y }\end{array}$ & $\begin{array}{l}\text { Domicil } \\
\mathrm{e}\end{array}$ \\
\hline \multicolumn{11}{|c|}{ Consumer life-styles } \\
\hline Shopping & & & & & & & $*$ & & & $*$ \\
\hline \multicolumn{11}{|l|}{ frequency } \\
\hline $\begin{array}{c}\text { Shopping } \\
\text { time }\end{array}$ & & $*$ & & $*$ & & & $*$ & & & \\
\hline \multicolumn{11}{|l|}{$\begin{array}{l}\text { How to } \\
\text { go }\end{array}$} \\
\hline shopping & & & & & & & & & & \\
\hline \multicolumn{11}{|l|}{$\begin{array}{l}\text { Favorite } \\
\text { channel }\end{array}$} \\
\hline $\begin{array}{c}\text { Favorite } \\
\text { goods }\end{array}$ & & & & & & & $*$ & & & \\
\hline \multicolumn{11}{|l|}{$\begin{array}{l}\text { Decision } \\
\text { making }\end{array}$} \\
\hline \multicolumn{11}{|l|}{$\begin{array}{l}\text { Spending } \\
\text { per }\end{array}$} \\
\hline \multicolumn{11}{|c|}{ Purchasing behaviors } \\
\hline \multicolumn{11}{|l|}{$\begin{array}{l}\text { Reasons } \\
\text { in } \\
\text { choosing } \\
\text { the } \\
\text { outlet }\end{array}$} \\
\hline $\begin{array}{l}\text { Reasons } \\
\text { in } \\
\text { choosing }\end{array}$ & & & & & & & & * & & \\
\hline $\begin{array}{c}\text { goods/bran } \\
\text { d }\end{array}$ & & & & & & & & & & \\
\hline $\begin{array}{c}\text { Service } \\
\text { expect }\end{array}$ & & & & & & & & $*$ & $*$ & \\
\hline $\begin{array}{c}\text { Promotion } \\
\text { expect }\end{array}$ & & & & & & & & & & \\
\hline
\end{tabular}


Table 3. Differences in consumers' attitudinal among traditional trade and modern trade channels

\begin{tabular}{cccc}
\hline Item & $\begin{array}{c}\text { Mean of attitude } \\
\text { Modern trade }\end{array}$ & $\begin{array}{c}\text { Mean of attitude } \\
\text { Traditional trade }\end{array}$ & t-test \\
\hline Outlet location & 4.28 & 3.20 & $17.3^{*}$ \\
Atmosphere in outlet & 4.32 & 3.12 & $18.5^{*}$ \\
Sales service & 4.07 & 3.13 & $12.4^{*}$ \\
Product price & 4.02 & 3.32 & $10.0^{*}$ \\
Distribution & 4.29 & 3.33 & $13.9^{*}$ \\
Publicity & 4.25 & 2.70 & $22.9^{*}$ \\
Sales Promotion & 4.16 & 2.73 & $19.9^{*}$ \\
Product quality & 4.16 & 3.19 & $16.0^{*}$ \\
Modernity of product & 4.36 & 3.06 & $19.5^{*}$ \\
Open \& close time & 4.21 & 3.19 & $14.8^{*}$ \\
Product variety & 4.27 & 2.95 & $19.6^{*}$ \\
Integrated service & 4.40 & 2.81 & $22.9^{*}$ \\
\hline
\end{tabular}

Note: ${ }^{* *} 5=$ very good, $4=$ good, $3=$ fair, $2=$ poor, $1=$ need to be improved

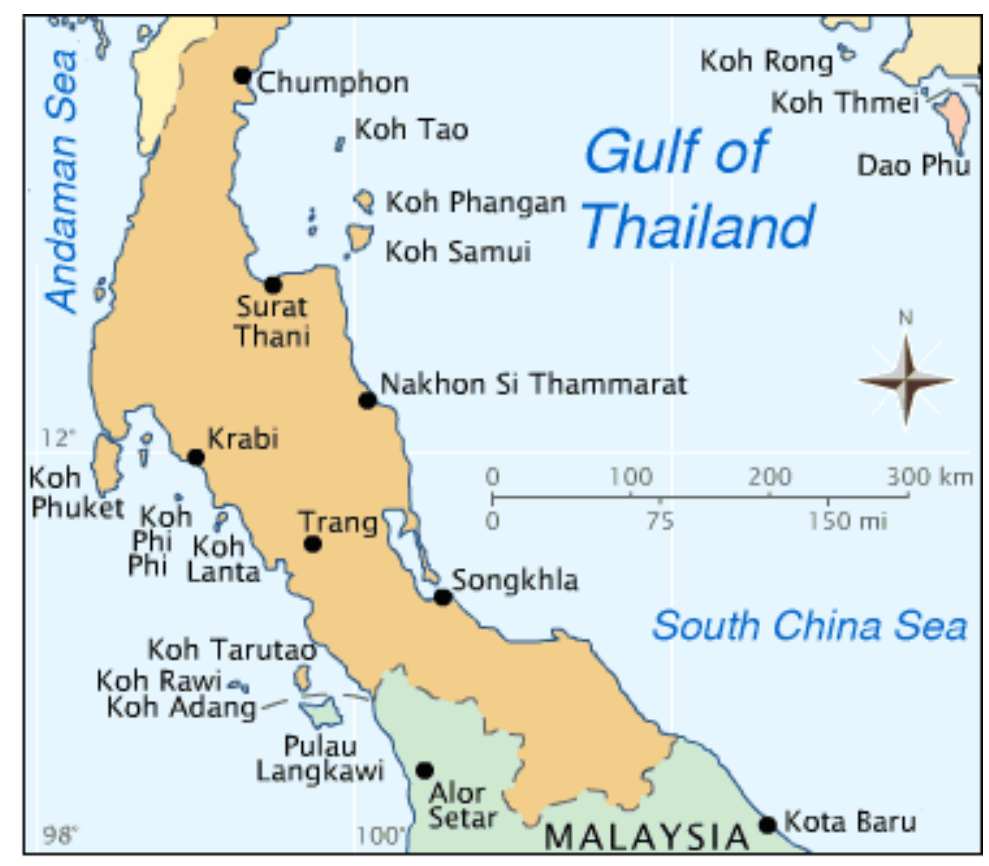

Figure 1. Map of Songkla province, Thailand 


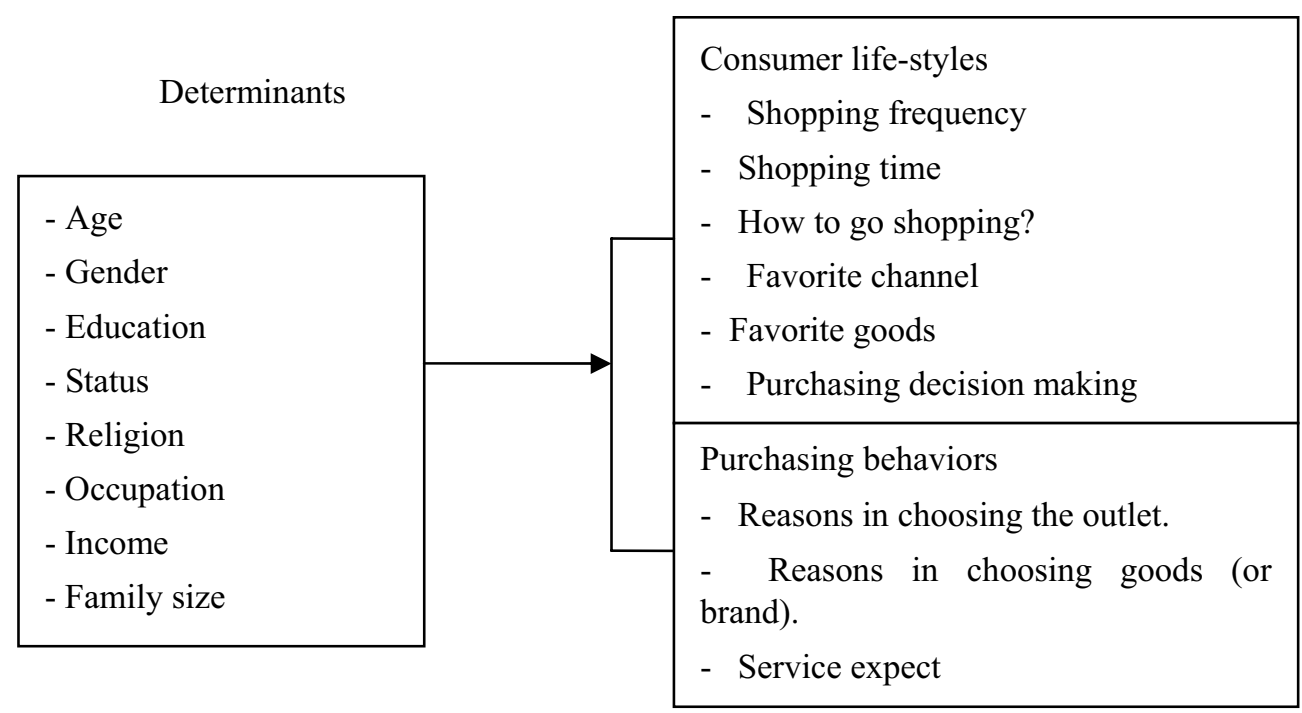

Figure 2. Research framework

Consumer life-styles

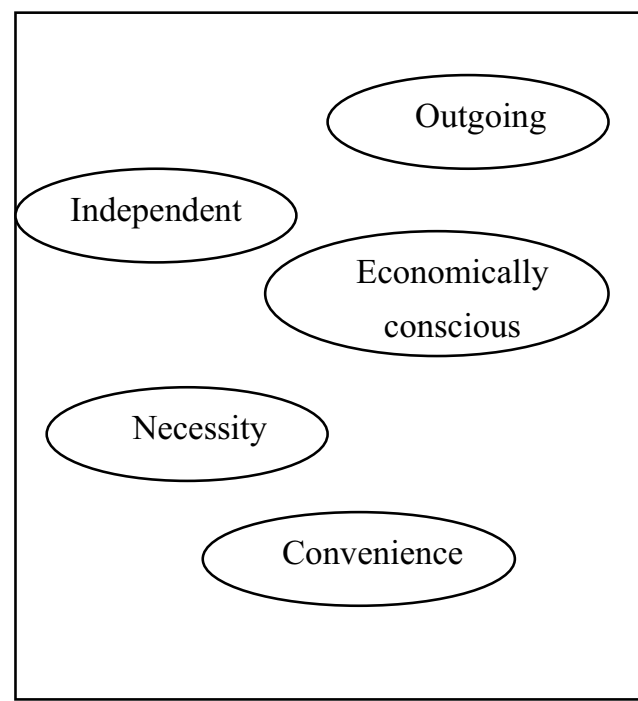

Purchasing behaviors

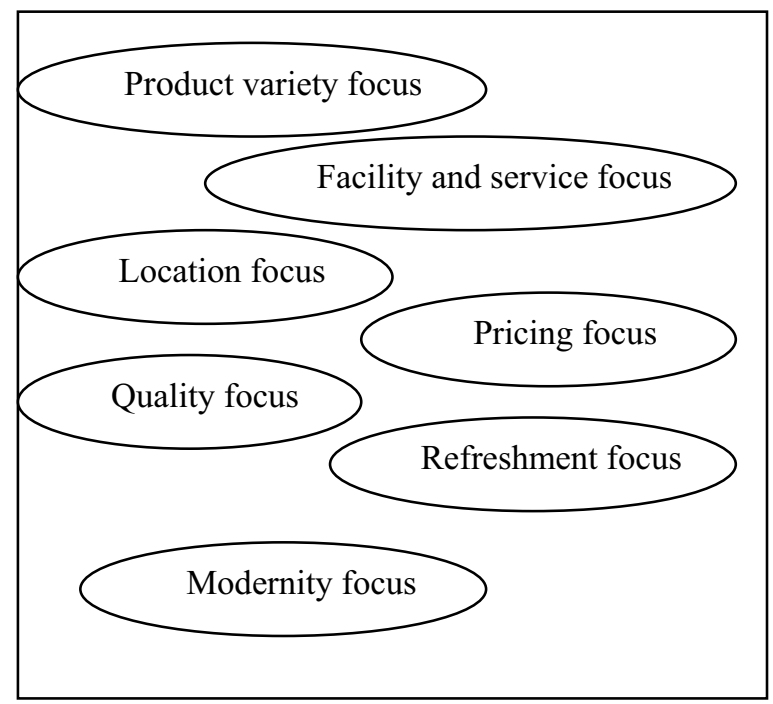

Figure 3. Distinct consumer life-styles and purchasing behaviors 